\title{
Sustainability in waterfront development in Malaysia: barriers to achieving best practices of waterfront development
}

\author{
M. N. Razali ${ }^{1}$, A. M. Yassin ${ }^{2}$, S. H. Mastor ${ }^{2}$ \& A. Z. Zainudin ${ }^{1}$ \\ ${ }^{1}$ Universiti Teknologi Malaysia, Malaysia \\ ${ }^{2}$ Universiti Tun Hussein Onn Malaysia, Malaysia
}

\begin{abstract}
In Malaysia, rivers were homes to vital communities and they initiated the emergence of cities around them. Population growth, economic growth, urbanisation and increased technology have transformed many Malaysian river systems from water industries into non-water industries. The focus of this study was to examine the level of success for sustainable waterfront development in Malaysia as well as to identify the barriers in achieving best practices in waterfront development in Malaysia. The findings of this research were based on the questionnaires mailed and e-mailed to property development companies listed by Bursa Malaysia in 2009. The findings indicated that the level of successful implementation of waterfront development in Malaysia was considered low. This was attributed by several reasons such as; difficulty in balancing the various social, economic and financial needs of the various stakeholders, no collaboration between stakeholders, and external interference and lack of human expertise. The attributes identified were then recommended to be improved in order to achieve best practices of waterfront development in Malaysia in future.
\end{abstract}

Keywords: best practice, successful waterfront development, waterfront, waterfront development.

\section{Introduction}

Rivers and water are valuable natural resources for human life, the environment and national development. Mann [1], however, sees a river as the "last open valley of the urban terrain, the last remaining path where man may re-establish his rights of access and enjoyment." In fact, almost $71 \%$ of the earth's surface is covered by water (Lalli and Parsons [2]). Sustainable planning ensures the revitalisation of 
river developments surrounding river areas in order to maintain the biodiversity of the river. Despite the importance of rivers for settlements and public space, their biodiversity and traditional importance as sources of primary and secondary production and their contribution to energy cycles is now becoming better appreciated (Constanza et al. [3], Lalli and Parsons [2], Zhang [4]).

The waterfront redevelopment phenomenon began in the early 1960s. Hoyle [5] explains that the emergence of waterfront redevelopment is mainly but not exclusively associated with maritime activity. The phenomenon grew in the 1970s, accelerated in the 1980s (Breen and Rigby [6]) and continues to the present day. In Malaysia, rapid development and urbanisation over decades caused the Malaysian government to start including many waterfront areas in future development with the focus on more recreational uses, while private property developers concentrated more on mixed-use development. However, in many cases, the implementation of waterfront development projects is driven more by investment needs rather than by community and environmental needs. In addition, inadequate regulations and guidelines relating to waterfront development at every level of government, is having a negative impact environmentally and socially such as water pollution and crime (Ali and Nawawi [7], Latip et al. [8]). Although some waterfront development projects continue to remain profitable, with good public access, many do not. Therefore, this paper aims to examine the level of successful sustainable waterfront development in Malaysia as well as to identify the obstacles in achieving best practices in waterfront development in Malaysia. The findings were then recommended in assisting property development companies when undertaking sustainable waterfront developments in the future.

\section{Review of the literature}

In general, the waterfront refers to land fronting on to water (Dong [9]). Even though the word waterfront itself is clear; some researchers prefer to use different words to replace the term waterfront, for example, city port, harbour front, riverside, river edge, water edge and riverfront (Hazreena [10], Hoyle [11], Mann [1], Tunbridge and Ashworth [12], Watson [13]).

The waterfront is a zone of interaction between urban development and the water and a waterfront area is considered to be a unique and irreplaceable resource where it interfaces between land, water, air, sun and productive plants (Wrenn [14]). Moreover, Ryckbost [15] sees waterfronts as any property that has a strong visual or physical connection to water with the water itself being any type of water body such as a lake, the ocean, a river or a stream of all sizes (Breen and Rigby [16]). In the development context, waterfront developments have various interpretations depending on the characteristics of the sites and the cities (Dong [9]). And, Butuner [17] sees waterfronts as land to be reclaimed from water in order to create an extension of existing city centres. Breen and Rigby $[6,16]$ consider that waterfront development may not necessarily need to directly front water but may need only to look as if it is attached to the water. They believe that a property with a commanding view of water can be considered as a waterfront property. 


\section{Research methodologies}

In this study, a quantitative research strategy was adopted as a strategy for data collection. The purpose of the quantitative method (questionnaire survey) in this research strategy was to statistically confirm the identified attributes associated with waterfront development in Malaysia. The survey was carried out within Malaysia and the respondents were property development companies listed under Bursa Malaysia. A stratified sampling procedure was used as part of probabilistic sampling (Sapsford and Jupp [18], Sekaran [19]). The sample data comprised firms listed under the property counter that traded at Bursa Malaysia during 2009. Considering that a waterfront development project requires strong financial records and sufficient and efficient management teams as well as excellent experience in the past, the selection of property development companies who were listed in Bursa Malaysia was therefore appropriate. As stated by Bursa Malaysia, only 91 property development companies were listed in 2009, Bursa Malaysia [20].

In this research, self-administered questionnaires [1] and the accompanying covering letter were mailed and e-mailed to the respondents who completed them individually. The aim was to motivate the respondents to answer the attached questions and then achieve as high a respondent rate as possible (Bourque and Fielder [21]). Despite several advantages (i.e. inexpensive, convenient for time and flexible), a self-administered questionnaire presents a challenge to the researcher because the researcher relies more on the clarity of the written questions rather than on her/his skills (Bourque and Fielder [21], Zikmund [22]). Also, the response rate tends to be much lower with mailed questionnaires as compared to other modes (Singleton and Straits [23]). Moreover, it also introduces a non-response bias as any doubts respondents might have cannot be clarified. Nevertheless, the selection of experienced respondents regarding waterfront development would increase the response rate and several follow-ups should yield the most reliable information, especially when closed-ended questions are used and the questionnaire is well structured (Singleton and Straits [23]). This will result in the researcher achieving the research objectives. The data collected from the survey was analysed using the Statistical Package for Social Science (SPSS). Two techniques were used in the data analysis process: Descriptive statistics and Cross tabulation analysis.

\section{Results and discussion}

The sample data comprises property development companies listed under Bursa Malaysia during 2009. Only 91 property development companies were listed in 2009 Bursa Malaysia [24]. Of the 91 questionnaires mailed and e-mailed to the respondents, 61 were returned within three months of the response period (survey was conducted between April and July, 2010). This resulted in a total of $67 \%$ useable response rate. Information on the property development companies who were respondents to the survey questionnaire was supplied as background information in order to provide more detail about the respondents. 
From the results, it appears that the range of the respondents represented in the sample were similar: they were property development companies that had been actively practising property development for many years and were listed in Bursa Malaysia.

\section{Sustainable waterfront development practise in Malaysia}

The overall finding in this study is that $32.8 \%$ of the property development companies undertook waterfront development projects in Malaysia, while the rest $(67.2 \%)$ were not involved in waterfront development in Malaysia or internationally. Out of the property developers involved in waterfront development, only $15 \%$ or 3 projects mentioned a sustainable concept as being implemented in their projects.

Of the $67.2 \%$ of respondents who did not undertake waterfront development projects, more than half $(58.6 \%)$ of the respondents are now motivated to undertake waterfront development in the future, $14.6 \%$ have decided not to undertake waterfront development in the future and $26.8 \%$ are still not sure whether to undertake waterfront development or not, depending on the financial support and demand for waterfront property at the time. In addition, 59\% of respondents perceived that a sustainable concept in waterfront development will place burden on the companies' budgets. However $24 \%$ of respondents were willing to take part in promoting sustainable waterfront development projects in the future. The opportunities perceived by respondents were based on the promotion and incentives that are provided by the government in promoting sustainable development in Malaysia. Based on these responses it appears that waterfront development in Malaysia may increase in the future. Of the one third of respondents who undertake waterfront development, over half $(60 \%)$ of them only incorporate between 1-20\% of waterfront development in their projects. $25 \%$ of respondents undertake waterfront development projects between $21-40 \%$ of the time, while $15 \%$ of them incorporate $41-60 \%$ of waterfront development in their projects. From the $32.8 \%$ of respondents who undertake waterfront development, $75 \%$ of them had undertaken waterfront development for residential use, $70 \%$ were developed for mixed-use and $25 \%$ were developed for recreational purposes. However, the results indicated that no companies developed waterfront projects for industrial use, while only 5\% developed them for 'other' uses. Out of these figures, all sustainable waterfront development is for a residential purpose, which will add value to residential projects, in terms of economic value, aesthetic quality and beautification. As such, it is indicated that most of the sustainable waterfront projects in Malaysia are implemented for residential projects. The results also indicated that "a profit/financial benefit" and "to diversify property type of development" considerations greatly influence the respondents' decisions as to whether to undertake waterfront development in Malaysia, accounting for 35\% for each response. $20 \%$ of the property development companies undertake waterfront development for the conservation of natural resources, while $10 \%$ undertake waterfront projects for 'other' reasons such as public benefit uses, such as to provide public amenities for locals and visitors. Table 1 summarises results for 
waterfront developments in Malaysia. For sustainable waterfront development projects, all 3 projects implemented the concept of sustainability in waterfront projects for the reasons as stated in the survey which are; profit/financial benefits, add value to the property, to promote sustainability concept and conservation of natural resources.

Table 1: Waterfront development in Malaysia.

\begin{tabular}{|c|c|c|}
\hline Variable & $n=61$ & Percent (\%) \\
\hline $\begin{array}{l}\text { Undertake waterfront development projects: } \\
\text { Yes } \\
\text { No }\end{array}$ & $\begin{array}{l}20 \\
41\end{array}$ & $\begin{array}{l}32.8 \\
67.2\end{array}$ \\
\hline $\begin{array}{l}\text { Sustainable waterfront development projects: } \\
\text { Yes } \\
\text { No }\end{array}$ & $\begin{array}{c}\mathbf{n}=\mathbf{2 0} \\
\mathbf{3} \\
\mathbf{1 7}\end{array}$ & $\begin{array}{l}15 \% \\
85 \%\end{array}$ \\
\hline $\begin{array}{l}\text { Undertake waterfront development projects in future: } \\
\text { Yes } \\
\text { No } \\
\text { Not sure }\end{array}$ & $\begin{array}{c}24 \\
6 \\
11\end{array}$ & $\begin{array}{l}58.6 \\
14.6 \\
26.8\end{array}$ \\
\hline $\begin{array}{l}\text { Undertake sustainable waterfront development projects in } \\
\text { future: } \\
\text { Yes } \\
\text { No } \\
\text { Not sure }\end{array}$ & $\begin{array}{c}18 \\
24 \\
0\end{array}$ & $\begin{array}{c}43 \\
59 \\
0\end{array}$ \\
\hline $\begin{array}{l}\text { Percentage of waterfront development projects: } \\
1-20 \% \\
21-40 \% \\
41-60 \%\end{array}$ & $\begin{array}{c}12 \\
5 \\
3\end{array}$ & $\begin{array}{l}60 \\
25 \\
15\end{array}$ \\
\hline $\begin{array}{l}\text { Type of waterfront development projects: } \\
\text { Residential } \\
\text { Commercial } \\
\text { Mixed-use } \\
\text { Industrial } \\
\text { Recreational } \\
\text { Other }\end{array}$ & $\begin{array}{c}15 \\
8 \\
14 \\
0 \\
5 \\
1\end{array}$ & $\begin{array}{c}75 \\
40 \\
70 \\
0 \\
25 \\
5\end{array}$ \\
\hline $\begin{array}{l}\text { Sustainable Waterfront development project by type of } \\
\text { properties: } \\
\text { Residential }\end{array}$ & 3 & 100 \\
\hline $\begin{array}{l}\text { Primary motive for undertaking waterfront development: } \\
\text { Profit/financial benefits } \\
\text { To diversify property type of development } \\
\text { Conservation of natural resources } \\
\text { Other }\end{array}$ & $\begin{array}{l}7 \\
7 \\
4 \\
2\end{array}$ & $\begin{array}{l}35 \\
35 \\
20 \\
10\end{array}$ \\
\hline $\begin{array}{l}\text { Primary motive for undertaking sustainable waterfront } \\
\text { development: } \\
\text { Profit/financial benefits } \\
\text { Add value to the property } \\
\text { To promote sustainability concept } \\
\text { Conservation of natural resources }\end{array}$ & $\begin{array}{r}\mathrm{n}=3 \\
3 \\
3 \\
3 \\
3\end{array}$ & $\begin{array}{l}100 \\
100 \\
100 \\
100\end{array}$ \\
\hline
\end{tabular}




\subsubsection{Successful sustainable waterfront development}

Overall, from 61 returned questionnaires, $44.2 \%$ of the respondents were unsure as to whether Malaysia had successful implementation of sustainable waterfront development or not. $41 \%$ of respondents firmly stated that waterfront developments undertaken in Malaysia were not successful as compared to other developed countries. Only $45 \%$ indicated that Malaysia had successfully implemented sustainable waterfront development.

On the other hand, of the 20 property development companies undertaking waterfront development projects in Malaysia, more than half $(60 \%)$ of them thought that Malaysia did not have successful implementation of sustainable waterfront developments. Table 2 presents the results of the successful implementation of waterfront development.

Table 2: Successful implementation of waterfront development and sustainable waterfront development.

\begin{tabular}{l|c|c|c|c}
\hline & $\begin{array}{c}\text { Yes } \\
\mathbf{n}(\%)\end{array}$ & $\begin{array}{c}\text { No } \\
\mathbf{n}(\%)\end{array}$ & $\begin{array}{c}\text { Unsure } \\
\mathbf{n}(\%)\end{array}$ & $\begin{array}{c}\text { Total } \\
\mathbf{n}(\%)\end{array}$ \\
\hline $\begin{array}{l}\text { Within all } \\
\text { development } \\
\text { companies }\end{array}$ & $3(5)$ & $58(95)$ & $27(44.2)$ & $61(100)$ \\
\hline $\begin{array}{l}\text { Within development } \\
\text { companies } \\
\text { undertaking } \\
\begin{array}{l}\text { waterfront } \\
\text { development projects }\end{array}\end{array}$ & $5(25)$ & $15(60)$ & $0(0)$ & $20(100)$ \\
\hline $\begin{array}{l}\text { Within development } \\
\text { companies who did } \\
\text { not undertake } \\
\text { waterfront } \\
\text { development projects }\end{array}$ & $5(12.2)$ & $16(39)$ & $20(48.8)$ & $41(100)$ \\
\hline
\end{tabular}

As shown in Table 3, factors that prevented the successful implementation of waterfront development were then investigated. The findings indicate that cost and maintenance is a major factor of unsuccessful of sustainable waterfront project in Malaysia. All groups of respondents perceived this factor as a major hurdle to ensure the successful to promote sustainability concept. Furthermore, 20\% of respondents thought that difficulty in balancing the social, economic and financial needs of the various stakeholders involved in the waterfront development projects was the most influential factor that prevented the successful implementation of waterfront development in Malaysia. That there is no collaboration between stakeholders involved in waterfront development was identified as a factor by $10 \%$ 
of the respondents. About $8 \%$ of respondents identified insufficient financial support as a reason for unsuccessful waterfront development, while less participation (domination by government and less involvement by nongovernment organisations) was suggested as a reason by $10 \%$ of respondents. The least number $(1 \%)$ of respondents identified several factors such as limited number of viable locations and difficulty on obtaining planning permission. for waterfront development as a factors that prevented successful waterfront development in Malaysia.

Table 3: Factors for unsuccessful implementation of sustainable waterfront development.

\begin{tabular}{l|c|c|c}
\hline \multicolumn{1}{c|}{ Factor } & $\begin{array}{c}\text { Group 1 } \\
\mathbf{n = 6 1} \\
\mathbf{( \% )}\end{array}$ & $\begin{array}{c}\text { Group 2 } \\
\mathbf{n = 2 0} \\
\mathbf{( \% )}\end{array}$ & $\begin{array}{c}\text { Group 3 } \\
\mathbf{n = 4 1} \\
\mathbf{( \% )}\end{array}$ \\
\hline $\begin{array}{l}\text { Difficulty in balancing the various } \\
\text { social, economic and financial } \\
\text { needs of the various stakeholders }\end{array}$ & $12(20)$ & $3(15)$ & $5(12)$ \\
\hline $\begin{array}{l}\text { No collaboration between } \\
\text { stakeholders }\end{array}$ & $10(48)$ & $2(10)$ & $4(10)$ \\
\hline $\begin{array}{l}\text { Insufficient financial resources } \\
\text { Less participation (domination by } \\
\text { government and less involvement } \\
\text { by non-government organisations) }\end{array}$ & $8(13)$ & $2(10)$ & $5(12)$ \\
\hline $\begin{array}{l}\text { Other - external interference and } \\
\text { lack of human expertise) }\end{array}$ & $5(10)$ & $1(5)$ & $2(10)$ \\
\hline Limited number of viable locations & $1(2)$ & $0(0)$ & $1(2)$ \\
\hline $\begin{array}{l}\text { Difficulty in obtaining planning } \\
\text { permission }\end{array}$ & $1(2)$ & $1(5)$ & $1(2.4)$ \\
\hline $\begin{array}{l}\text { Cost and maintenance } \\
\text { Awareness among developers }\end{array}$ & $6(10)$ & $3(15)$ & $4(10)$ \\
\hline
\end{tabular}

* Group 1 = All respondents; Group 2 = Respondents who undertook waterfront development; Group 3 = Respondents who did not undertake waterfront development.

On the other hand, from the $32.8 \%$ of respondents who undertake waterfront development, $3 \%$ of them thought that difficulty in balancing social, economic and financial needs between various stakeholders was a main factor that contributed to the unsuccessful implementation of sustainable waterfront development in Malaysia. Moreover, about $2 \%$ of respondents identified insufficient financial support for the development as a reason for the unsuccessful implementation of sustainable waterfront development projects. This is similar with other factors such as insufficient financial resources and less participation from government and 
non-government organisations. None of the respondents indicated the limited number of viable locations for sustainable waterfront development as a main reason for the unsuccessful implementation of sustainable waterfront development in Malaysia. These results are supported by the literature that determined that successful sustainable waterfront development could be achieved through a combination of several factors such as financial feasibility, environmental approval, effective management, construction technology, stakeholders participation and sharing benefits etc. (Bertsch [25], Bruttomesso [26], Mann [1], Torre [27], Tumbde [28]). Moreover, a lack of manpower and technical expertise, development approaches that prioritise economic and engineering feasibility and a low priority in the allocation of funds for landscaping and beautification works were identified as reasons the government failed to improve the environmental quality in Malaysia (Dewan Bandaraya Kuala Lumpur [29]). Previous research focusing on the social impact of waterfront development indicated that successful waterfront development was significant in increasing household income, job opportunities, regional business sales and tourism (Krausse [30], Parsons and $\mathrm{Wu}$ [31], Rexhausen and Vredeveld [32]). In addition, waterfront redevelopment provided better safety and access to downtown areas and also created new economic activities (Small and Arnott [33]). Thus, apparently, in order to achieve and maintain economically viable waterfront development, a combination of several factors that could result in successful sustainable waterfront development is recommended, for the practice of waterfront development in Malaysia.

\section{Conclusions}

The focus of this research was to examine the level of success of waterfront development in Malaysia, in particular, the level of sustainability, as well as to identify the obstacles in achieving best practices in sustainable waterfront development in Malaysia. These results showed that the level of successful implementation of sustainable waterfront development in Malaysia is considered low. The major obstacle in the implementation of a sustainable waterfront concept in Malaysia was cost and maintenance. In addition, there were several reasons attributed to the unsuccessful implementation of waterfront development in Malaysia such as; difficulty in balancing the various social, economic and financial needs of the various stakeholders, no collaboration between stakeholders, and external interference and lack of human expertise. The identified attributes were then recommended to be improved in order to achieve best practices wihtin waterfront development in Malaysia in the future.

\section{Acknowledgement}

This paper is part of a research university grant (GUP) funded by Universiti Teknologi Malaysia and Ministry of Education under Vot No. 10J02. Thank you for your generous support. 


\section{References}

[1] Mann, R. (Ed.). (1973). Rivers in the city. Newton Abbot: David \& Charles.

[2] Lalli, C. M., \& Parsons, T. R. Biological oceanography: An introduction (1st ed.). Oxford: Elsevier Buttorworth - Heinemann.

[3] Costanza, R., Andrade, F., Antunes, P., Belt, M. v. d., Boesch, D., Boersma, D., Ecological economics and sustainable governance of the oceans. Ecological Economics, 31: 171-187.

[4] Zhang, L. An evaluation an urban riverfront park, Riverfront Park, Spokane, Washington - Experience and lessons for designer. Unpublished master thesis, Washington State University, US.

[5] Hoyle, B. Urban waterfront revitalization in developing countries: the example of Zanzibar's Stone Town. The Geographical Journal, 168(2): 141-162.

[6] Breen, A., \& Rigby, D. Waterfronts: Cities reclaim their edge. US: McGraw-Hill.

[7] Ali, S. M., \& Nawawi, A. H. The social impact of urban waterfront landscapes: Malaysian perspectives. Paper presented at the $14^{\text {th }}$ International Conference on Urban Planning, Regional Development and Information Society $\left(22^{\text {nd }}-25^{\text {th }}\right.$ April 2009), Centre de Disseny de Sitges Catalonia/Spain, retrieved $12^{\text {th }}$ December, 2008, from http://programm.corp.at/cdrom2009/papers2009/CORP2009 15.pdf.

[8] Latip, N. S. A., Heath, T., Shamsuddin, S., Liew, M. S., \& Vallyutham, K.. The contextual integration and sustainable development of Kuala Lumpur's city centre waterfront: An evaluation of the policies, law and guidelines. Paper presented at the The World, Engineering, Science and Technology Congress (ESTCON 2010) $\left(15^{\text {th }}-17^{\text {th }}\right.$ June 2010), Kuala Lumpur Convention Centre, Malaysia, retrieved $29^{\text {th }}$ January, 2011, from eprints.utp.edu.my/2811/1/SBI-06-CI-07.pdf.

[9] Dong, L. Waterfront development: A case study of Dalian, China. University of Waterloo, Canada.

[10] Hazreena, H. Urban recreational riverfronts: Successful revitalization elements. Journal of Design and the Built Environment, 2 (1).

[11] Hoyle, B. Lamu: Waterfront revitalisation in an East African port-city. Cities, 18(5), 297-313.

[12] Tunbridge, J. \& Ashworth, G. Leisure resource development in cityport revitalisation: the tourist-historic dimension. In B. Hoyle \& D. Pinder (Eds.), European port cities in transition (pp. 177-199). London: Belhaven Press.

[13] Watson, J. S. Ross's landing: A river edge park opportunity. Paper presented at the 2nd International Conference on Making Cities Liable.

[14] Wrenn, D. M. Urban Waterfront Development. Washington, D.C: The Urban Land Institute.

[15] Ryckbost, P. Redeveloping urban waterfront property, retrieved $19^{\text {th }}$ June, 2008, from www.umich.edu/ econdev/waterfronts/. 
[16] Breen, A. \& Rigby, D. The new waterfront: A worldwide urban success story. New York: McGraw-Hill.

[17] Butuner, B. Waterfront Revitalisation as a Challengeing Urban Issu. Paper presented at the 42nd ISoCaRP Congress.

[18] Sapsford, R., \& Jupp, V. Data collection and analysis (2nd ed.). London: SAGE Publications.

[19] Sekaran, U. Research methods for business: A skill building approach (4th ed.). New York: John Wiley \& Sons.

[20] Bursa Malaysia. Kuala Lumpur, Malaysia: Bursa Malaysia.

[21] Bourque, L. B., \& Fielder, E. P. How to conduct self-administered and mail surveys. London: SAGE Publications.

[22] Zikmund, W. G. Business research methods (7th ed.). US: Thompson Learning.

[23] Singleton, R. A., \& Straits, B. C. Approaches to social research (5th ed.). New York: Oxford University Press.

[24] Bursa Malaysia. Products and services. Retrieved $20^{\text {th }}$ January, 2009, from http://www.bursamalaysia.com/website/bm/.

[25] Bertsch, H. The key elements to successful waterfront design. Real Estate Weekly, 54.39.

[26] Bruttomesso, R. Waterfront development: A strategic choice for cities on water. Paper presented at the Waterfront Development Forum: China Maritime (02 ${ }^{\text {nd }}$ March 2006), Hong Kong, retrieved $24^{\text {th }}$ January, 2009, from www.harbourbusinessforum.com/download/060303 transcript.pdf.

[27] Torre, L. A. Waterfront development. New York: Van Nostrand Reinhold.

[28] Tumbde, D. Conceptual model for economically viable urban riverfront revitalization in US. Unpublished master thesis, University of Cincinnati, retrieved $18^{\text {th }}$ August, 2010, from rave.ohiolink.edu/etdc/view?acc_num=ucin1123542011.

[29] Dewan Bandaraya Kuala Lumpur. Kuala Lumpur Structure Plan. Kuala Lumpur: Kuala Lumpur City Hall.

[30] Krausse, G. H. Tourism and waterfront renewal: Assessing residential perception in Newport, Rhode Island, USA. Ocean and Coastal Management, 26(3), 179-203.

[31] Parsons, G. R., \& Wu, Y. The opportunity cost of coastal land-use controls an empirical analysis Land Economics, 67(3), 308-316.

[32] Rexhausen, J., \& Vredeveld, G. Riverfront investment: Economic impact on the Cincinnati Metropolitan Area. Economic Development Journal, Spring 2003, 8.

[33] Small, K. A., \& Arnott, R. J. The economics of traffic congestion. American Scientist, 82(446-455). 